\title{
The role of agroforestry areas of the province of Bari in the absortion of carbon dioxide
}

\author{
Pasquale Dal Sasso, Giuseppe Ruggiero, Maria Antonella Ottolino, Giuseppe Verdiani \\ Department of Agro - Environmental Sciences (DISAAT), University of Bari, Italy
}

\begin{abstract}
Agroforestry areas have a significant and recognized productive, socio - economic, environmental and landscape role. An important ecological function performed by these areas is the net absorption of considerable quantities of atmospheric carbon dioxide. The scientific knowledge of the $\mathrm{CO}_{2}$ assimilation capacity of agroforestry ecosystems in a territory, is a useful and innovative means to support territorial planning. In the interests of environmental sustainability, emissions from human activities carried out in a specific local context, must be adapted by the simultaneous capacity of $\mathrm{CO}_{2}$ sequestration. For the protection of environmental quality, the choice of land use should therefore optimize the circuit of interaction between emissions and absorption. This work takes into account the agroforestry areas of the Province of Bari to estimate the potential capacity to absorb $\mathrm{CO}_{2}$ and compare it, with the current emission levels.
\end{abstract}

\section{Introduction}

During the twentieth century there has been an increase of the average global temperature of about $0.75^{\circ} \mathrm{C}$ (Hansen, 2000; Hansen, 2001; Hansen, 2005).

The main cause of this phenomenon, as stated in much of the scientific community, is the progressive increase in atmospheric concentration of climate-altering gases (or greenhouse gases), that absorb and

Correspondence: Giuseppe Verdiani, Department of Agro - Environmental Sciences (DISAAT), University of Bari, via Amendola 165/A 70126 Bari, Italy. Tel/Fax: +39.0805442964. E-mail: giuseppeverdiani@hotmail.it

Key words: environmental analysis, $\mathrm{CO}_{2}$ absorption, ecological balance.

Acknowledgements: the present work has been carried out under the Project Research of the University of Bari Criteria for assessing the environmental carrying capacity of the rural environment.

Received for publication: 12 July 2011.

Accepted for publication: 11 January 2012.

(C) Copyright P. Dal Sasso et al., 2012

Licensee PAGEPress, Italy

Journal of Agricultural Engineering 2012; XLIII:e3

doi:10.4081/jae.2012.e3

This article is distributed under the terms of the Creative Commons Attribution Noncommercial License (by-nc 3.0) which permits any noncommercial use, distribution, and reproduction in any medium, provided the original author(s) and source are credited. radiate in all directions the infrared radiation emitted by the earth.

The main source of greenhouse gases and natural gases are carbon dioxide $\left(\mathrm{CO}_{2}\right)$, nitrous oxide $\left(\mathrm{N}_{2} \mathrm{O}\right)$, methane $\left(\mathrm{CH}_{4}\right)$ and halogenated compounds (CFCs, HCFCs). On a global basis, $\mathrm{CO}_{2}, \mathrm{CH}_{4}$ and $\mathrm{N}_{2} \mathrm{O}$ emissions contribute respectively $60 \%, 15 \%$ and $5 \%$ of the anthropogenic greenhouse effect (Rodhe, 1990) and therefore on global warming.

The increase in $\mathrm{CO}_{2}$ in the atmosphere (Reth, 2005) caused by human activity (Koch, 2000) and by the use of fossil fuels (Roulet, 2000; Sims, 2001) has a major role in global warming. Since the beginning of the industrial era, to the present, atmospheric concentration of carbon dioxide, has in fact increased from 280 parts per million by volume (ppmv) to about 375 ppmv (Marland, 2005) and, according to most reliable estimates, they could reach values of 540-970 ppmv during the twenty-first century (Pettenella, 2006). In addition, other greenhouse gases have increased their atmospheric concentrations, and to quantify their contribution to global warming, the Global Warming Potential (GWP) has been introduced. The GWP is the ratio between the heating induced by generic gas emissions, and that induced by the same amount of carbon dioxide over a period of 100 years. GWP values, calculated by the Intergovernmental Panel on Climate Change (IPCC) (2000), are used as conversion factors, for all greenhouse gas emissions in $\mathrm{CO}_{2}$ equivalent (Table 1).

Global warming has a significant impact on rainfall patterns, on the spread of pests and pathogens, on the change in the distribution of species and habitats, and on raising sea levels (Parmesan, 1996; Edwards, 2004; Thuiller, 2005). Therefore, it is necessary to counteract the causes of climate change, through mitigation and compensation of greenhouse gas emissions, to protect ecosystems and the health of present and future generations. For this purpose, the Kyoto Protocol was signed in 1997 by more than 160 countries and entered into force in 2005 , setting compulsory targets of greenhouse gas emission over the period 2008 to 2012. To achieve these targets, the Kyoto Protocol has set out a number of measures for the prevention and reduction of greenhouse gas emissions. These objectives can be achieved by improving energy efficiency, renewable energy and the diffusion of advanced technologies for reduction of polluting emissions from industry.

The Kyoto Protocol provides, among other measures, to use the potentiality of the agro forestry sector to absorb carbon dioxide through the use of carbon sink for the reduction of the net national balance emissions of greenhouse gases. In this context, agroforestry activities are affected by climate change and simultaneously contribute to the increase or absorption of gas emission (Pettenella, 2006).

The management of agroforestry activities can then take action on two fronts: reducing emissions of greenhouse gases $\left(\mathrm{CO}_{2}, \mathrm{CH}_{4}, \mathrm{~N}_{2} \mathrm{O}\right)$ and absorption of $\mathrm{CO}_{2}$. According to a European Environment Agency report, in 2002 agriculture contributed up to $10.1 \%$ of total emissions of greenhouse gases in the European Union (EEA, 2005) and this data is confirmed on a national scale (Gaudioso, 2004).

The main greenhouse gases produced by agriculture, are nitrous oxide and methane. Methane emissions are related to animal husbandry and rice cultivation, while emissions of nitrogen oxides result from nitrogen fertilization and manure. Besides, agriculture consumes fossil 
fuels for various productive operations (manufacturing, irrigation, treatments, etc.) producing $\mathrm{CO}_{2}$ emissions. At the same time, the agroforestry territory, has a positive role in terms of carbon fixation in the soil, crop, tree and forest biomass (Houghton, 2003; Ciccarese, 2005). The potential of carbon sequestration through the management of plant resources was estimated in a range between 60 and $87 \mathrm{Gt}$ of carbon for a period of 50 years, equivalent to $7-15 \%$ of average emissions of fossil fuels for the period 2000-2050 (IPCC, 2000; Houghton, 2003). Agriculture and forestry has therefore an important role in climate change mitigation for their contribution to atmospheric carbon fixation. The forest ecosystems' function in carbon storage is known and recognized while the agroecosystem one, although not insignificant, is still poorly investigated and considered. Recent studies show that even crops help atmospheric $\mathrm{CO}_{2}$ absorb (Tortora, 2006; Gramegna, 2008) by acting as carbon sinks. The production and ecological functions of agriculture play a significative role in the reduction of carbon dioxide concentration in the atmosphere and, consequently, in the mitigation of climate change (Pettenella, 2006). Even intensified agroecosystems can act as a carbon sink despite the high direct and indirect energy inputs required for cultivation (Chang, 2011). The amount of carbon sequestered by the different vegetation formations is related to agricultural practices, crop residue management (Gramegna, 2008), climatic features (Marland, 2001), method of irrigation and amount of biomass. In the literature there are numerous estimates and measures of the potential carbon fixation of most representative Italian agroforestry systems. The objective of this study was to evaluate the real potentiality of agroforestry areas in the Province of Bari in carbon dioxide absorption in order to develop an eco-balance of $\mathrm{CO}_{2}$ fluxes, on a regional scale. Thus, we have verified the Daly's principle of sustainability stating that gas emission rates, shall not exceed the assimilative capacity of natural ecosystems. The approaches used in literature to estimate the maximum emissions that a territory may absorb are based on the ratio of ventilation and dispersion models (Goyal, 2007). In this study, the verification of $\mathrm{CO}_{2}$ absorption capacity by agro forestry areas within the territory of the Province of Bari, has been conducted through the application of a methodological procedure. The knowledge of carbon dioxide absorption potentiality on a regional scale may provide useful support in the land planning process, that must take into account the environmental sustainability of land-use choices (Candura, 2009).

\section{Materials and methods}

In this work the evaluation of carbon dioxide atmospheric emissions and the verification of the agroforestry ecosystems absorption capacity in the area of study has been conducted through the stages of analysis and data processing described below.

\section{Evaluation of the emission}

In the first phase were analyzed and quantified anthropogenic and natural emissions of carbon dioxide broken down in 2005 by socio-economic macro-sectors of activity through consulting the National Inventory of Air Emissions. The National Inventory of Air Emissionsis the most comprehensive, consistent and transparent source of information on emissions at regional and provincial levels. The inventory database is based on the INEMAR (Inventory Emissions to Air) and collects the emissions broken down by activity, territorial unit and type of air pollutant (ANPA, 2001). Punctual and diffuse emissions are estimated using the CORINAIR methodology (Coordination Information Air) based on data measured at the plants and the emission factors proposed in the literature.

\section{Assessment of agroforestry ecosystems absorption}

In the second phase, the data on net carbon dioxide exchange by different plant species were identified and extracted from the bibliographic sources of sector (Gramegna, 2008; Facini, 2007; Matteucci, 2007; Spano, 2007; Ventura, 2007; Ceotto, 2006; Anthoni, 2004; Berretti, 2007). Forest ecosystems and agroecosystems play a known and recognized role in the national balance reduction of emissions of carbon dioxide and in the literature there are numerous studies aimed at evaluating the level of net ecosystem exchange of $\mathrm{CO}_{2}$. The net ecosystem exchange of $\mathrm{CO}_{2}$ [Net Ecosystem Exchange (NEE)] represents the difference between the carbon dioxide absorbed Gross Primary Production (GPP) and the carbon dioxide emitted through autotrophic $\left(\mathrm{R}_{\mathrm{A}}\right)$ and heterotrophic $\left(\mathrm{R}_{\mathrm{E}}\right)$ respiration processes. The global carbon balance depends on the absorbed photosynthetically active radiation, on the atmospheric $\mathrm{CO}_{2}$ concentrations, on the air temperature, on the pressure deficit steam, on the amount of soil nitrogen available to plants and on the LAI (Leaf Area Index). The literature absorption values of $\mathrm{CO}_{2}$ that different plant species are able to remove from the atmosphere (Table 2 and Figure 1) determined by using the eddy covariance technique in climate and agro-environmental contexts similar to those that characterize the study area, were used in this work.

The eddy covariance is a micrometeorological technique based on the turbulent transfer that allows to analyze direct and continuous net $\mathrm{CO}_{2}$ exchanges between vegetation and atmosphere over vast areas, homogeneous in terms of vegetation.

The net carbon dioxide absorption of temperate forests was estimated at the average value of $14.6 \mathrm{tCO}_{2} \mathrm{ha}^{-1} \mathrm{y}^{-1}$ (Matteucci, 2007) according to the results obtained with the eddy covariance technique in Italian forest areas.

The net carbon dioxide absorption of sclerophyllous vegetation in the

Table 1. Global warming potential values for the main greenhouse gases (Climate Change Working Group 1, 1995).

\begin{tabular}{lc} 
Gas & GWP100 \\
Carbon dioxide $\left(\mathrm{CO}_{2}\right)$ & 1 \\
Methane $\left(\mathrm{CH}_{4}\right)$ & 21 \\
\hline Nitrous oxide $\left(\mathrm{N}_{2} \mathrm{O}\right)$ & 310 \\
HFC-23 & 11,700 \\
\hline SF6 & 23,900 \\
\hline
\end{tabular}

GWP, global warming potential.

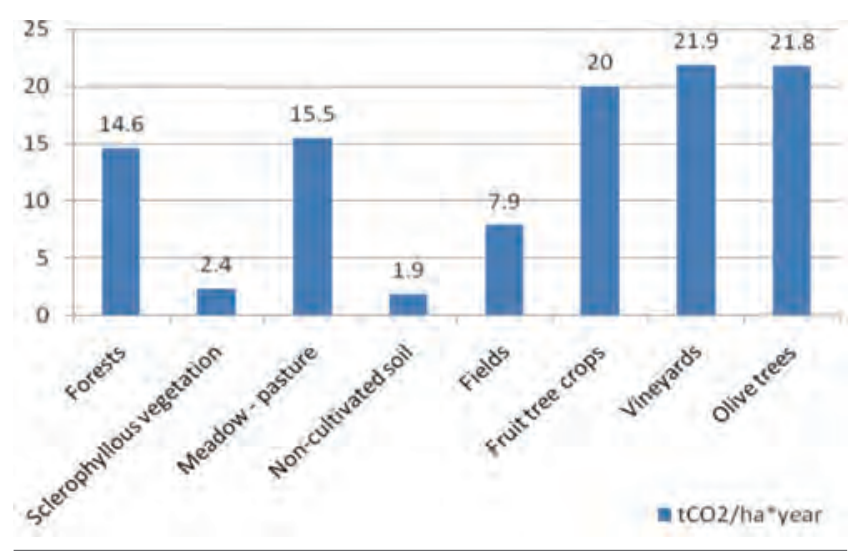

Figure 1. Absorption of $\mathrm{CO}_{2}$ in the main forestry and agroecosystems. 
Sardegna Region measured using the same technique was equal to 2.4 $\mathrm{tCO}_{2} \mathrm{ha}^{-1} \mathrm{y}^{-1}$ (Spano, 2007) even if it is strongly related to a highly variable composition (Costa, 2005). The fruit tree crops have a net absorption of $\mathrm{CO}_{2}$ between 3 and $8 \mathrm{tCO}_{2}$ ha $^{-1} \mathrm{y}^{-1}$ (Facini, 2007) or between 10 and $30 \mathrm{tCO}_{2} \mathrm{ha}^{-1} \mathrm{y}^{-1}$. The net carbon dioxide absorption in an olive grove located in the Puglia Region was determined by the eddy covariance technique equal to $21.8 \mathrm{tCO}_{2} \mathrm{ha}^{-1} \mathrm{y}^{-1}$ (Gramegna, 2008). The olive trees are characterized by high photosynthetic activity throughout the year and consequently they have a high potential for carbon fixation. The vineyards are able to sequestrate about $6 \mathrm{tC} \mathrm{ha}^{-1} \mathrm{y}^{-1}$ (Ventura, 2007) amounted to $21.96 \mathrm{tCO}_{2} \mathrm{ha}^{-1} \mathrm{y}^{-1}$. These values were estimated on the measurements made with the eddy covariance technique in a vineyard in the Toscana Region concerning an average growing season of 150 days (Ventura, 2007). The eddy covariance technique has also been used to monitor the flow of $\mathrm{CO}_{2}$ in a meadow - pasture of the Trentino Region. The net balance was equal to $460 \mathrm{gC} \mathrm{m}^{-2} \mathrm{y}^{-1}$ in 2003 and $387 \mathrm{gC} \mathrm{m}^{-2} \mathrm{y}^{-1}$ in 2004 (Berretti, 2007) then we can estimate the meadows and pastures as having a net absorption of about $15.5 \mathrm{tCO}_{2} \mathrm{ha}^{-1} \mathrm{y}^{-1}$. The interannual difference of net absorption of $\mathrm{CO}_{2}$ was effected by weather conditions because 2003 was characterized by higher temperatures.

The vegetable fields, characterized by different annual harvests and marked by a low net sequestration of carbon, are still weakly studied. For example, the wheat crops are characterized by a net ecosystem exchange between 245 and $185 \mathrm{gC} \mathrm{m}^{-2} \mathrm{y}^{-1}$ (Anthoni, 2004) of approximately 7.9 $\mathrm{tCO}_{2} \mathrm{ha}^{-1} \mathrm{y}^{-1}$. The annual amount of carbon that can be sequestered in non-cultivated soil varies from $50 \mathrm{kgC} \mathrm{ha}^{-1}$ to $1000 \mathrm{kgC} \mathrm{ha}^{-1}$ (Ceotto, 2006 ) in relation to carbon immobilized in soil. The non-cultivated soil is therefore characterized by a net absorption of $\mathrm{CO}_{2}$ average of $1.9 \mathrm{tCO}_{2}$ $\mathrm{ha}^{-1} \mathrm{y}^{-1}$. In order to estimate the absorption of $\mathrm{CO}_{2}$ in the local context chosen as the study area, the literature values of the potential carbon fixation of the main forestry and agroecosystems have been associated with land use classes of the CORINE Land Cover 2000 (Table 2). From the land use thematic map of the Puglia Region (Servizio Cartografico della Regione Puglia, 2006), produced in a 1:5000 scale, agricultural and forest areas of the study were calculated and classified according with the current use of the land. The study was conducted in the Province of Bari

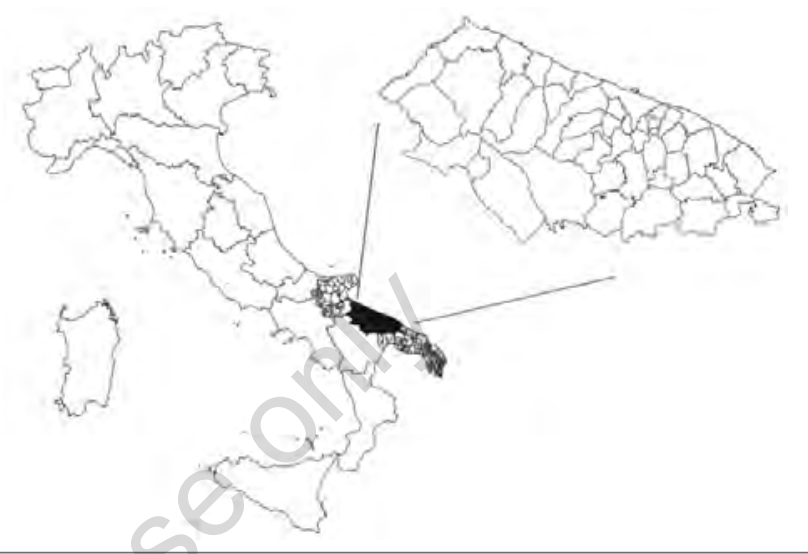

Figure 2. Province of Bari in the Mediterranean context.

Table 2. $\mathrm{CO}_{2}$ absorption of the selected land use classes.

\begin{tabular}{|c|c|c|c|c|}
\hline Classes of land use & Agroforestry systems & $\begin{array}{l}\text { ibsorption by } \\
\text { orestry systems } \\
\text { (ha/year) }\end{array}$ & $\begin{array}{l}\text { Bibliographic } \\
\text { source }\end{array}$ & $\begin{array}{l}\mathrm{CO}_{2} \text { absorption } \\
\text { for classes of } \\
\text { land use } \\
\left(\mathrm{tCO}_{2} / \mathrm{ha} / \text { year) }\right.\end{array}$ \\
\hline Coniferous forests & Coniferous forests & 14.6 & Matteucci, 2007 & 14.6 \\
\hline Broadleaf forests & Broadleaf forests & 14.6 & Matteucci, 2007 & 14.6 \\
\hline $\begin{array}{l}\text { Mixed woods of conifers } \\
\text { and hardwoods }\end{array}$ & $\begin{array}{l}\text { Coniferous forests } \\
\text { Broadleaf forests }\end{array}$ & $\begin{array}{l}14.6 \\
14.6\end{array}$ & $\begin{array}{l}\text { Matteucci, } 2007 \\
\text { Matteucci, } 2007\end{array}$ & 14.6 \\
\hline $\begin{array}{l}\text { Woods and pastures } \\
\text { lined with trees }\end{array}$ & $\begin{array}{l}\text { Coniferous forests } \\
\text { Broadleaf forests } \\
\text { Meadow - pasture }\end{array}$ & $\begin{array}{l}14.6 \\
14.6 \\
15.5\end{array}$ & $\begin{array}{l}\text { Matteucci, } 2007 \\
\text { Matteucci, } 2007 \\
\text { Berretti }\end{array}$ & 14.9 \\
\hline Pasture and natural grassland & $\begin{array}{l}\text { Non-cultivated soil } \\
\text { Meadow - pasture }\end{array}$ & $\begin{array}{r}1.9 \\
15.5\end{array}$ & $\begin{array}{l}\text { Ceotto, } 2006 \\
\text { Berretti }\end{array}$ & 8.7 \\
\hline Bushes and shrubs & $\begin{array}{l}\text { Coniferous forests } \\
\text { Broadleaf forests } \\
\text { Meadow - pasture }\end{array}$ & $\begin{array}{l}14.6 \\
14.6 \\
15.5\end{array}$ & $\begin{array}{l}\text { Matteucci, } 2007 \\
\text { Matteucci, } 2007 \\
\text { Berretti }\end{array}$ & 14.9 \\
\hline Sclerophyllous vegetation areas & Sclerophyllous vegetation & 2.4 & Spano, 2007 & 2.4 \\
\hline $\begin{array}{l}\text { Areas of forest vegetation and } \\
\text { shrubs in evolution }\end{array}$ & $\begin{array}{l}\text { Sclerophyllous vegetation } \\
\text { Non-cultivated soil }\end{array}$ & $\begin{array}{l}2.4 \\
1.9\end{array}$ & $\begin{array}{l}\text { Spano, } 2007 \\
\text { Ceotto, } 2006\end{array}$ & 2.2 \\
\hline Non irrigated arable land & Fields & 7.9 & Anthoni, 2004 & 7.9 \\
\hline Arable land irrigated & Fields & 7.9 & Anthoni, 2004 & 7.9 \\
\hline Permanent crops: vineyards & Vineyards & 21.9 & Ventura, 2007 & 21.9 \\
\hline Permanent crops: fruit orchards and small & Fruit tree crops & $10-30$ & Facini, 2007 & 20 \\
\hline Permanent crops: olive groves & Olive trees & 21.8 & Gramegna, 2008 & 21.8 \\
\hline Permanent grassland & Meadow - pasture & 15.5 & Berretti & 15.5 \\
\hline All agroforestry & $\begin{array}{l}\text { Fields } \\
\text { Vineyards } \\
\text { Fruit tree crops } \\
\text { Olive trees } \\
\text { Meadow - pasture }\end{array}$ & $\begin{array}{c}7.9 \\
21.96 \\
10-30 \\
21.89 \\
4.23\end{array}$ & $\begin{array}{l}\text { Anthoni, } 2004 \\
\text { Ventura, } 2007 \\
\text { Facini, } 2007 \\
\text { Palese, } 2004 \\
\text { Berretti }\end{array}$ & 17.4 \\
\hline
\end{tabular}


(Figure 2) characterized by the presence of multiple sources of emission and having a land area of 513,019 ha and an agro-forest area of 374,159 ha. The potentiality of agroforestry areas in the Province of Bari in carbon dioxide uptake was determined by multiplying the values of absorption attributed to each class of land use for the related surface. This processing was carried out assuming constant values of climatic parameters for the values of temperature, humidity and wind. Finally, an ecological balance was made between the emissions and those absorbed by the agricultural and forest ecosystems.

\section{Results and discussion}

In the province of Bari we verified the balance between $\mathrm{CO}_{2}$ emitted by human activities and potentially absorbable by agroforestry areas through identifying the amount of $\mathrm{CO}_{2}$ emissions, evaluating the theoretical potential of absorption of the agroforestry systems, and finally decreasing the amount of the latter value of $\mathrm{CO}_{2}$ equivalent emitted from agroforestry activities.

Table 3. $\mathrm{CO}_{2}$ emissions of the main macrosectors in the Province of Bari.

\begin{tabular}{lcc} 
Description macrosectors & Units & Emissions (2005) \\
Power production and fuel processing & $\mathrm{t}$ & $353,439.0$ \\
Non-industrial combustion & $\mathrm{t}$ & $1,095,400.4$ \\
\hline Industrial combustion & $\mathrm{t}$ & $430,759.1$ \\
Production processes & $\mathrm{t}$ & $441,010.7$ \\
\hline Use of solvent & $\mathrm{t}$ & $25,406.0$ \\
Road transport & $\mathrm{t}$ & $2,594,976.4$ \\
\hline Other mobile sources and machinery & $\mathrm{t}$ & $353,239.9$ \\
Total & $\mathrm{t}$ & $5,294,231.5$ \\
\hline
\end{tabular}

\section{Emissions of $\mathrm{CO}_{2}$ in the atmosphere in the Province of Bari}

In 2005 the amount of carbon dioxide produced by the multiple emissive sources in the Province of Bari was 5,294,231.5 $\mathrm{t}$ (INEMAR). $\mathrm{CO}_{2}$ emissions in the atmosphere are produced in varying degrees by each socio-economic macro-sector according to the amounts reported in Table 3.

\section{$\mathrm{CO}_{2}$ uptake in agroforestry areas of the Province of Bari}

GIS-based cartographic processing has allowed to determine the land area occupied by different classes of land use in the province of Bari assessing, on a regional scale, the $\mathrm{CO}_{2}$ absorption potential capacity of agroforestry areas of the Province of Bari, which turns out to be a total of 6,014,617.619 $\mathrm{tCO}_{2} /$ year (Table 4).

The land use classes contribute differently to the $\mathrm{CO}_{2}$ absorption in the studied local context because of their extent and the absorption potential capacity that characterize the relative plant species (Figure 3). Olive groves and vineyards in the Province of Bari give a significant contribution to the establishment of carbon dioxide equivalent to $60 \%$ of the global absorption capacity of the entire agroforestry surface.

\section{Greenhouse gases produced by agroforestry activities}

Agroforestry areas have a positive role on the net balance of carbon dioxide in the Province of Bari, even if they emit other greenhouse gas contaminants into the atmosphere. Emissions of greenhouse gases directly related to agricultural activities are those related to the release of nitrous oxide $\left(\mathrm{N}_{2} \mathrm{O}\right)$ during the process of nitrification and denitrification as a result of fertilization and the methane production resulting from enteric fermentation in ruminants. In the study area, the agricultural activity produced in 2005 the emission of $1443.1 \mathrm{t}$ of nitrous oxide and of $6571.8 \mathrm{t}$ of methane (INEMAR). These emissions can be converted into $\mathrm{CO}_{2}$ equivalent through the use of the GWP values calculated by the Intergovernmental IPCC (Table 5).

Table 4. $\mathrm{CO}_{2}$ absorption for classes of land use in the Province of Bari.

\begin{tabular}{|c|c|c|c|}
\hline Classes of land use & $\begin{array}{l}\mathrm{CO}_{2} \text { absorption for } \\
\text { classes of land use } \\
\left(\mathrm{tCO}_{2} / \mathrm{ha} \text { /year }\right)\end{array}$ & $\begin{array}{c}\text { Surface for classes } \\
\text { of land use (ha) }\end{array}$ & $\begin{array}{l}\mathrm{CO}_{2} \text { total absorption for } \\
\text { classes of land use } \\
\left(\mathrm{tCO}_{2} / \text { year }\right)\end{array}$ \\
\hline Coniferous forests & 14.6 & $15,190.8$ & $221,786.3$ \\
\hline Broadleaf forests & 14.6 & 4203.2 & $61,366.4$ \\
\hline Mixed woods of conifers and hardwoods & 14.6 & 4012.0 & $58,575.5$ \\
\hline Woods and pastures lined with trees & 14.9 & 4109.9 & $61,236.9$ \\
\hline Pasture and natural grassland & 8.7 & $40,731.2$ & 354.4 \\
\hline Bushes and shrubs & 14.9 & 2969.6 & $44,246.3$ \\
\hline Sclerophyllous vegetation areas & 2.4 & 1344.8 & 3227.4 \\
\hline Areas of forest vegetation and shrubs in evolution & 2.2 & 0 & 0 \\
\hline Non irrigated arable land & 7.9 & $174,348.1$ & $1,377,350.1$ \\
\hline Arable land irrigated & 7.9 & 3088.4 & $24,398.1$ \\
\hline Permanent crops: vineyards & 21.9 & $46,231.4$ & $1,012,467.4$ \\
\hline Permanent crops: fruit orchards and small & 20 & $30,700.2$ & $614,004.4$ \\
\hline Permanent crops: olive groves & 21.8 & $149,824.4$ & $3,266,170.8$ \\
\hline Permanent grassland & 15.5 & 640.2 & 9923.1 \\
\hline \multirow[t]{2}{*}{ All agroforestry } & 17.4 & 0 & 0 \\
\hline & & & $7,109,113.7$ \\
\hline
\end{tabular}




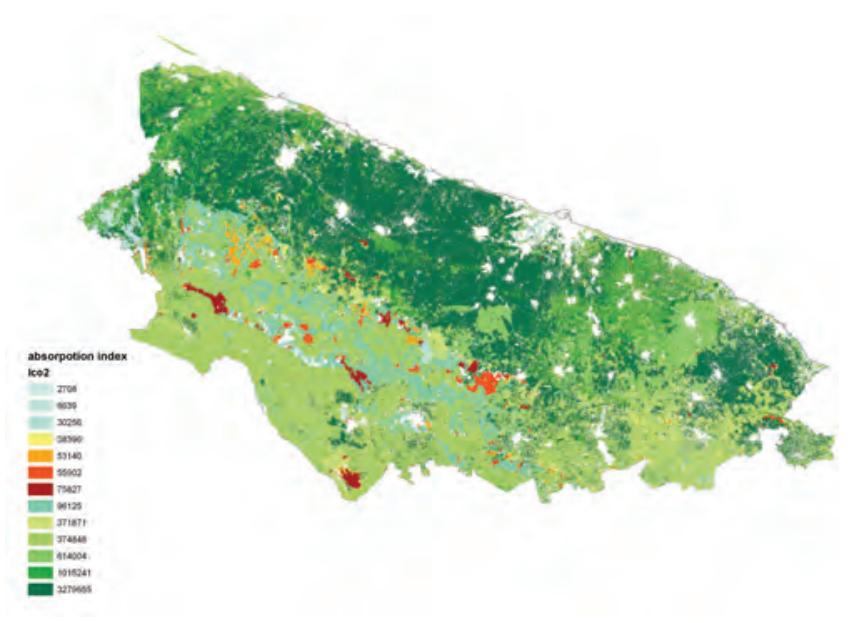

Figure 3. Territorial distribution of $\mathrm{CO}_{2}$ absorption in the Province of Bari.

Table 5. Emission of greenhouse gas produced by agriculture in the Province of Bari.

\begin{tabular}{lccc} 
Air contaminant & $\begin{array}{c}\text { Emission } \\
(\mathrm{t})\end{array}$ & $\begin{array}{c}\text { GWP } \\
(\mathrm{t})\end{array}$ & $\mathrm{CO}_{2}$ equivalent \\
Nitrous oxide & 1443.1 & 310 & 447374.4 \\
Methane & 6571.8 & 21 & 138007.7 \\
\hline Total & & & 585382.1 \\
\hline
\end{tabular}

\section{Environmental territorial balance $\mathrm{CO}_{2}$ emissions}

In the Province of Bari the balance between emitted $\mathrm{CO}_{2}$ and absorbable $\mathrm{CO}_{2}$ is in favor of the latter also thanks to the high amount of arable land used for tree crops. In 2005, in the Province of Bari $5,294,231.5 \mathrm{tCO}_{2}$ have been released into the atmosphere against a potential absorption of 7,109,113.7 $\mathrm{tCO}_{2}$ /year by agroforestry systems.

Agroforestry areas can potentially give away 1,814,882.2 $\mathrm{tCO}_{2}$ /year to the atmosphere, more than the carbon dioxide emissions in 2005 found in the National Emission Inventory. However, the agricultural and zootechnical activities in the Province of Bari cause the emission into the atmosphere of 585,382.1 tonnes of $\mathrm{CO}_{2}$ equivalent. These emissions reduce the role of agroforestry areas in absorbing carbon dioxide and mitigate climate change. The remaining potential capacity of carbon dioxide absorption of agroforestry areas of the Province of Bari is $1,229,500 \mathrm{tCO}_{2}$ /year.

\section{Conclusions}

The knowledge of the $\mathrm{CO}_{2}$ assimilation potential capacity, on a territorial scale, by agro ecosystems can be a valuable tool for determining the emission limits, in a specific geographical area, useful to regulate the establishment and operation of production activities. At the same time, this knowledge can allow to regulate the cultivation transformations in relation to the relationship between types of UAA (utilized agricultural area) and quantity of emissions/absorptions.

The geographical distribution of $\mathrm{CO}_{2}$ absorbing areas also provides useful information to guide farmers towards forms of production to lower emission of greenhouse gases and subject to environmental pro- tection forms the in areas of higher absorption. It is clear that rural areas can not be related to a single municipality or to the territory of one province. However, it is relevant to summarize the environmental performance of administrative areas also through the values, parameters and indicators related to the specific balance of emissions/ removals.

\section{References}

Agenzia Nazionale per la Protezione dell'Ambiente, 2001. Linee guida agli inventari locali di emissioni in atmosfera.

Anthoni PM, Freibauer A, Kolle 0, Schulze ED, 2004. Winter wheat carbon exchange in Thuringia, Germany. Agricult. Forest. Meteorol. 121:55-67.

Berretti F, Baronti S, Lanini M, Maracchi G, Raschi A, Stefani P, 2007. Bilancio dei flussi di tre gas serra (CO2, $\mathrm{CH} 4, \mathrm{~N} 20)$ in un pratopascolo alpino: confronto tra 2003 e 2004. Clima e cambiamenti climatici: le attività di ricerca del CNR.

Candura A, Dal Sasso P, Marinelli G, 2009. Analisi multi criteri e GIS per la facilitazione delle scelte di pianificazione. Atti del 9th Convegno Nazionale dell'Associazione Italiana di Ingegneria Agraria, Ischia, Italy.

Chang J, Wu X, Liu A, Wang Y, Xu B, Yang W, Meyerson LA, Gu B, Peng C, Ge Y, 2011. Assessment of net ecosystem services of plastic greenhouse vegetable cultivation in China. Ecol. Econ. 70:740-748.

Ceotto E, Marletto V, 2006. Dalle paglie dei cereali un contributo a Kyoto? Agricoltura 2006;117-119.

Ciccarese L, Brown S, Schlamadinger B, 2005. Carbon sequestration through restoration of temperate and boreal forests. Restoration of boreal and temperate forests. In: J Stunturf and P Madsen (eds.) Restoration of temperate and boreal forests. CRC Press/Lewis Publishers. CRC Press. Boca Raton, USA, Chap. 7, pp. 111-120.

Costa G, La Mantia T, 2005. Il ruolo della macchia mediterranea nel sequestro del carbonio. Forest@ 2:378-387.

Edwards M, Richardson AJ, 2004. Impact of climate change on marine pelagic phenology and trophic mismatch. Nature 430:881-884.

European Environment Agency, 2005. The European Environment: State and Outlook 2005. Part A. Integrated Assessment European Environment Agency.

Facini 0, Georgiadis T, Nardino M, Rossi F, Maracchi G, Motisi A, 2007. Il contributo degli impianti da frutto all'assorbimento della $\mathrm{CO} 2$ atmosferica. Clima e Cambiamenti Climatici, le attività del CNR.

Gaudioso D, 2004. Annuario dei dati ambientali. Agenzia per la protezione dell'ambiente e per i servizi tecnici - Servizio Interdipartimentale Informativo Ambientale, Italy.

Goyal SK, Chalapati Rao CV, 2007. Air assimilative capacity-based environment friendly siting of new industries - A case study of Kochi region, India. J. Environ. Manag. 84:473-483

Gramegna D, Di Gioia F, Lavarra P, Pastorelli AM, Sani R, Ungaro N, 2008. Valutazione Ambientale di Incidenza su Area Vasta della centrale turbogas di Modugno (Bari). Atti del $14^{\circ}$ Convegno di Igiene Industriale, Corvara, Italy.

Hansen J, Sato M, Ruedy R, Lacis A, Oinas V, 2000. Global warming in the twenty-first century: An alternative scenario. Proc. Natl. Acad. Sci. U.S.A. 97:9875-9880.

Hansen JE, Ande Sato M, 2001. Trends of measured climate forcing agents. Proc. Natl. Acad. Sci. U.S.A. 98:14778-14783.

Hansen J, Nazarenko L, Ruedy R, Sato M, Willis J, Del Genio A, Koch K, Lacis A, Lok K, Menon S, Novakov T, Perlwitz J, Russell G, Schmidt GA, Tausnev N, 2005. Earth's energy imbalance: confirmation and Implications. Science 308:1431-1435. 
Houghton RA, 2003. Revised estimates of the annual net flux of carbon to the atmosphere from changes in land use and land management 1850-2000. Tellus 55:378-390.

INEMAR. Inventory Emissions to Air. Available from: http:/www.inemar. eu/xwiki/bin/view/Inemar/WebHome

IPCC, 2000. Land use, land-use change and forestry. In: RT Watson, IR Noble, B Bolin, NH Ravindranath, DJ Verardo, DJ Dokken DJ. Special Report of the Intergovernmental Panel on Climate Change. Cambridge University Press, UK.

Koch J, Dayan U, Mey-Marom A, 2000. Inventory of emissions of greenhouse gases in Israel. Water Air Soil Pollut. 123:259-271.

Marland G, Fruit K, Sedjo R, 2001. Accounting for sequestered carbon: the question of permanence. Environ. Sci. Pol. 4:259-268.

Marland G, Boden TA, Andres RJ, 2005. Global, Regional, and National C02 Emissions. In: Trends: A Compendium of Data on Global Change. Carbon Dioxide Information Analysis Center, Oak Ridge National Laboratory, US Department of Energy, Oak Ridge, Tenn., USA.

Matteucci G, Scarascia Mugnozza G, 2007. Ecosistemi forestali e mitigazione dei cambiamenti climatici: sequestro di carbonio in foreste italiane. Clima e cambiamenti climatici: le attività di ricerca del CNR.

Palese AM, Sofo A, Cementano G, Xiloyannis C, 2004. Stoccaggio della C02 ambientale in giovani piante di olivo. Atti Convegno Europeo "Il futuro dei sistemi olivicoli in aree marginali:aspetti socio-economici, gestione delle risorse naturali e produzioni di qualità", Matera, Italy.

Parmesan C, 1996. Climate and species' range. Nature 382:765-766.

Pettenella D, Zanchi G, Ciccarese L, 2006. Il settore primario e la riduzione delle emissioni di gas ad effetto serra. Tra strumenti diretti di compensazione e politiche generiche di sostegno del settore. Politica Agricola Internazionale 5:27-48.

Reth S, Gockede M, Falge E, 2005. C02 efflux from agricultural soils in Eastern Germany - comparison of a closed chamber system with eddy covariance measurements. Theor. Appli. Climat. 80:105-120.

Rodhe H, 1990. A comparison of the contribution of various gases to the greenhouse effect. Science 248:1217-1219.

Roulet NT, 2000. Peatlands, carbon storage, greenhouse gases, and the Kyoto protocol: Prospects and significance for Canada. Wetlands 20:605-615.

Servizio Cartografico della Regione Puglia, 2006. Carta Tecnica Regionale.

Sims PL, Bradford JA, 2001. Carbon dioxide fluxes in a southern plains prairie. Agricult. Forest Meteorol. 109:117-134.

Spano D, 2007. Stima del patrimonio di carbonio forestale e rurale: le prospettive per la Regione Sardegna. Convegno "Lotta ai cambiamenti climatici: il ruolo delle aree agroforestali”.

Thuiller W, Lavorel S, Araujo MB, Sykes MT, Prentice IC, 2005. Climate change threats to plant diversity in Europe. Proc Natl. Acad. Sci U.S.A. 102:8245-8250.

Tortora A, Capobianco RL, Picuno P, 2006. Historical Cartography and GIS for the analysis of carbon balance in rural environment: a Study Case in Southern Italy. Agric. Eng. Int.: CIGR Journal, Vol. 8.

Ventura F, Facini 0, Georgiadis T, Nardino M, Rossi F, 2007. Indagine sui flussi di materia ed energia da vigneto e da terreno nudo nell'interfilare in un sistema viticolo dell'Italia centrale. Quaderni Viticoli Enologico Università di Torino, Italy.

Working Group on Climate Change, 1995. The Science of Climate Change: Summary for Policymakers. Technical Summary of the Working Group I Report. 